\title{
Analisis Variasi Pengelolaan Appendicitis Acuta di Rumah Sakit Wava Husada Malang
}

\section{Variation Analysis of Appendicitis Acute Management in Wava Husada Hospital}

\author{
Muzzamil', Muhammad Mansur', Muhammad Arif $S^{3}$ \\ ${ }^{1}$ Politeknik Kesehatan Kemenkes Malang \\ ${ }^{2}$ Program Studi Magister Manajemen Rumah Sakit Fakultas Kedokteran Universitas Brawijaya Malang \\ ${ }^{3}$ Rumah Sakit Wava Husada Kepanjen Malang
}

\begin{abstract}
ABSTRAK
Pelayanan appendicitis tidak menerapkan sistim paket dan mengalami banyak variasi, termasuk variasi biaya. Peneliti telah melakukan penelitian data catatan rekam medis terhadap pasien appendicitis acuta bulan Juni, Juli dan Agustus 2013 dengan jumlah sampel 21 pasien. Data dianalisa menggunakan regresi linier untuk mengetahui hubungan antara berbagai variabel. Analisa hubungan antara biaya obat dan biaya tindakan terhadap biaya total perawatan menunjukkan bahwa biaya obat dan biaya tindakan sangat berpengaruh terhadap biaya total perawatan $\left(r^{2}=0,731, p<0,001\right)$. Analisa hubungan antara biaya total perawatan dengan lama perawatan menunjukkan bahwa pasien yang membayar lebih mahal dirawat lebih lama dan pengaruh biaya terhadap lama perawatan sebesar $29,8 \%\left(r^{2}=0,296, p=0,011\right)$. Variasi pelayanan pasien menyebabkan variasi pada total biaya perawatan. Salah satu cara untuk mengurangi variasi, terdapatnya kendali mutu dan biaya adalah penerapan clinical pathway.
\end{abstract}

Kata Kunci: Appendicitis akut, clinical pathway, kendali biaya, kendali mutu, variasi pelayanan

\section{ABSTRACT}

Appendicitis care does not implement a package system and encountered many variations, including cost variations. The researchers have conducted research of the patient medical record data on acute appendicitis in June, July and August 2013 with a sample of 21 patients. The data were analyzed using linear regression to determine the relationship between various variables. Analysis of the relationship between drug costs and measures costs to the total cost of care shows that the drug cost and the measures cost affect the total cost of care. $(r 2=0,731, p<0,001)$ analyzes on the relationship between the total cost of care and the duration of treatment shows that patients whopaid more weretreated longer and the influence on cost of the treatment was $29,8 \%(r 2=0,296, p=0,011)$. Variations in patient care led to variations in the total cost of care. One way to reduce variation and cost, and the presence of quality control is the application of clinical pathways.

Keywords: Acute appendicitis, clinical pathways, cost control, quality control, service variations,

Jurnal Kedokteran Brawijaya, Vol. 28, Suplemen No.1 2014: Muzzamil. Politeknik Kesehatan Kemenkes Malang, Jl. Besar ljen No. 77 C Malang Tel.(0341)571388Email:dr.muzzamilsaja@gmail.com 


\section{PENDAHULUAN}

Operasi appendicitis acuta merupakan tindakan operasi kedua terbanyak sesudah persalinan sectio caesarea di Rumah Sakit Wava Husada (RSWH). Penelitian pendahuluan pada data rekam medis pasien appendicitis acuta di RSWH ditemukan variasi pada: lama perawatan, obat yang dipakai, pemeriksaan penunjang, jenis anastesi, jenis dan sifat operasi serta biaya tindakan operasi. Diantara variasi tersebut yang paling berpengaruh terhadap jumlah total biaya perawatan adalah biaya tindakan diikuti oleh biaya obat.

Penanganan pasien appendicitis acuta membutuhkan tindakan yang cepat dan tepat karena terlambatnya penanganan akan meningkatkan risiko baik karena tindakan appendiktomi maupun perjalanan penyakitnya. Komplikasi dan mortalitas akan meningkat dengan bertambahnya waktu terutama pada pasien tua dan anakanak (1). Walaupun kadang-kadang sulit untuk menegakkan diagnosa, tindakan appendiktomi harus sudah diputuskan dalam hitungan jam karena risiko akan meningkat dengan bertambahnya waktu (2).

Salah satu metode yang dapat mengurangi terjadinya makro variasi (lama perawatan, alur pasien), mikro variasi (diagnosa, pengobatan, prosedur) dan biaya adalah clinical pathway (3). Clinical pathway (CP) secara nyata bisa menurunkan biaya perawatan dengan tetap mempertahankan kualitas pelayanan $(4,5)$. Pengendalian mutu dan biaya bisa dilakukan karena CP disusun bersama oleh setiap profesi yang menangani pasien di rumah sakit, diantaranya adalah: dokter, case manager, perawat, farmasi, fisioterapi dan yang lainnya (6). Penelitian ini bertujuan untuk mengetahui besarnya variasi yang terjadi pada penatalaksanaan pasien appendicitis acuta sebagai dasar dalam penyusunan CP di RSWH untuk mengurangi variasi, meningkatkan kualitas pelayanan dan mengendalikan biaya.

\section{METODE}

Sebagai dasar dalam pengembangan CP dilakukan analisis pola dan variasi pelayanan di RSWH sebagai bentuk local evidence based. Dilakukan pengumpulan dan analisa data yang berasal dari rekam medik pada bulan Juni, Juli dan Agustus 2013 dengan seluruh kasus sebanyak 21. Uji statistik untuk mengetahui hubungan antara beberapa variabel menggunakan analisis regresi linier. Identitas dokter ditulis sebagai dokter A, dokter B dan dokter $\mathrm{C}$ dan pasien sebagai pasien nomer 1 sampai nomer 21 untuk menjaga kerahasiaan.

\section{HASIL}

\section{Variasi Penatalaksanaan Pasien Appendicitis acuta}

Terdapat beberapa variasi penatalaksanaan appendicitis acuta yang memberikan dampak berbeda. Beberapa variasi yang ditemukan adalah: golongan operasi (operasi besar atau kecil), sifat operasi (cito atau elektif), jenis anestesi, pemeriksaan ultrasonography (USG) sebagai alat bantu diagnosa, obat-obatan yang dipakai, jasa dokter operator, lama perawatan, pemeriksaan patologi anatomi dan rerata biaya. Setiap dokter operator memiliki rata-rata lama perawatan pasien berbeda, masingmasing 3,67 hari, 4,2 hari, dan 5 hari. Lama perawatan pasien appendicitis akut tanpa komplikasi antara 2 sampai 4 hari,sedangkan pasien dengan komplikasi bisa mencapai
9 hari. Sebagian dokter tidak melakukan pemeriksaan USG pada sebagian pasiennya, bahkan ada yang tidak melakukan pemeriksaan USG untuk beberapa kasus appendiktomi elektif. Persentase pasien yang dilakukan pemeriksaan USG setiap dokter berkisar antara 67-100\%. Persentase operasi appendiktomi cito masing-masing dokter adalah 33\%, 80\% dan 84,6\%. Prosedur standar di RSWH menggolongkan appendiktomi sebagai tindakan cito, tetapi seorang dokter cenderung melakukan operasi elektif.

Pengamatan menunjukkan variasi penggunaan obat dan kecenderungan penggunaan obat non generik. Meskipun harga obat non generik lebih mahal, penggunaannya tidak memberikan masa perawatan yang lebih pendek dibandingkan penggunaan obat generik (Tabel 1).

Tabel 1. Perbandingan antara harga ceftriaxon generik dan non generik dengan lama perawatan

\begin{tabular}{ccccc}
\hline No & $\begin{array}{c}\text { Nama } \\
\text { Obat }\end{array}$ & $\begin{array}{c}\text { Jumlah } \\
\text { Pasien }\end{array}$ & Harga (Rp) & $\begin{array}{c}\text { Rerata lama } \\
\text { perawatan }\end{array}$ \\
\hline 1 & Ceftriaxon & 1 & 10.527 & 4,00 hari \\
2 & B----------n & 9 & 229.075 & 3,89 hari \\
3 & C----------n & 4 & 235.813 & 5,25 hari \\
\hline
\end{tabular}

Pasien appendiktomi sebagian tidak dilakukan pemeriksaan patologi anatomi, meskipun pemeriksaan tersebut sangat dibutuhkan untuk memastikan kebenaran diagnosa. Tidak dilakukannya pemeriksaan patologi anatomi bisa mempersulit rumah sakit apabila terdapat masalah hukum di kemudian hari, terutama apabila pasien atau keluarganya merasa dirugikan dan mengajukan tuntutan.

Rerata total biaya perawatan pasien berbeda untuk setiap dokter, masing-masing adalah Rp. 12.127.444, Rp. 12.151.405 dan Rp. 15.433.187. Perbedaan rerata biaya total perawatan pasien kelas 3 antara tertinggi dengan yang paling rendah adalah $\mathrm{Rp}$. 4.841.629. Rerata biaya operasi juga bervariasi antar kelas perawatan yaitu Rp. 5.195.200, Rp. 5.947.166 dan Rp. 9.070.333.

Hasil uji menunjukkan bahwa secara parsial maupun simultan biaya obat dan tindakan mempunyai pengaruh signifikan terhadap total biaya perawatan. Semakin tinggi biaya tindakan dan biaya obat akan semakin meningkatkan biaya total perawatan. Faktor biaya obat dan tindakan menjelaskan $73,1 \%$ variasi biaya total perawatan. Hal ini menunjukkan besarnya kontribusi biaya obat dan tindakan terhadap total biaya perawatan. Jika biaya obat meningkat Rp 1.000 dan biaya lain dianggap konstan, maka biaya total perawatan meningkat sebesar $\mathrm{Rp}$ 1.481. Jika biaya tindakan meningkat $\mathrm{Rp} 1.000$ dan faktor biaya lain dianggap konstan, maka biaya total perawatan meningkat sebesar Rp 1.639.

Peningkatan biaya total akan diikuti oleh peningkatan lama perawatan dan penurunan biaya totalakan menyebabkan penurunan pada lama perawatan. Apabila terdapat peningkatan total biaya sebesar Rp 1.000 .000 maka lama perawatan akan meningkat sebesar 0,256 jam $(15,36$ menit). $R$ Square 0,298 yang berarti bahwa pengaruh antara variabel $X$ terhadap $Y$ sebesar $29,8 \%$ dan sisanya sebesar $70,2 \%$ disebabkan oleh variabel lain yang tidak diamati pada penelitian ini. 
Tabel 2. Hubungan antara biaya obat dan tindakan terhadap biaya total perawatan

\begin{tabular}{|c|c|c|c|c|c|c|c|c|}
\hline Model & & $\begin{array}{c}\text { Unst. } \\
\text { Coeff. B }\end{array}$ & Std. Error & $\begin{array}{c}\text { Standar. } \\
\text { coeff. B }\end{array}$ & $T$ & Sig & $R$ squ. & $\begin{array}{c}\text { Uji } \\
\text { simultan }\end{array}$ \\
\hline Biaya obat dan & Konstanta (a) & 5853251 & 1217499 & & 4,808 & 000 & & $F=24,404$ \\
\hline Tindakan thd & Obat (b1) & 1,481 & ,428 & ,487 & 3,460 & ,003 & 731 & Sig. $=, 000$ \\
\hline Biaya total & Tindakan (b2) & 1,639 & ,460 & ,502 & 3,566 & ,002 & & \\
\hline Biaya total thd & Konstanta & 1,071 & 1,191 & & ,899 & 380 &, 298 & \\
\hline Lama perawatan & Biaya & $2,56 \mathrm{E}-007$ & ,000 & ,546 & 2,838 & ,011 & & \\
\hline
\end{tabular}

\section{DISKUSI}

Rata-rata lama perawatan pasien appendicitis acute di RSWH bervariasi. Menurut beberapa penelitian, lama perawatan pasien tergantung pada ada tidaknya komplikasi, penyakit penyerta, kemampuan rumah sakit dalam mengendalikan infeksi nosokomial, usia, status gizi dan sebagainya. Penelitian di rumah sakit dr. Kariadi Semarang menunjukkan bahwa pasien appendiktomi dewasa tanpa komplikasi rata-rata mengalami rawat inap 3,8 hari. Di Inggris pada tahun 1985 anak yang mengalami appendiktomi tanpa perforasi yang dalam 48 jam pertama dipulangkan mencapai $80 \%$. Walaupun pasien bisa dipulangkan lebih cepat tapi banyak dokter yang tidak melakukannnya karena kuatir timbulnya infeksi luka operasi dan nyeri pasca operasi yang menghambat mobilisasi pasien. Pemberian analgesik akan mengurang rasa nyeri sehingga mobilisasi bisa dipercepat dan risiko infeksi bisa dikurangi dengan memberikan antibiotika profilaksis yang adekuat (7).

Sebagian pasien RSWH didiagnosa tanpa didahului pemeriksaan USG yang prosentasenya berbeda antara ketiga dokter operator. Kemampuan dan pengalaman setiap dokter dalam melakukan pemeriksaan klinis sangat beragam. Menegakkan diagnosa hanya berdasarkan gejala klinis berisiko karena angka ketepatannya dibawah $80 \%$. Kesalahan diagnosa dapatmenyebabkan negative appendictomy (appendiktomi pada pasien dengan appendik normal) yang jumlahnyasekitar 15 sampai $30 \%$ (8). Negative appendictomy dapat menyebabkan masa perawatan lebih lama jika dibandingkan dengan pasien appendicitis (9).

Ultrasonography (USG) merupakan alat bantu yang aman dan bisa mengurangi tingkat kesalahan dalam diagnosis (10), meningkatkan ketepatan dan kecepatan diagnosa appendicitis secara klinis, mengurangi eksplorasi yang tidak perlu dan menurunkan angka kejadian negative appendictomy serta menghindari penundaan operasi $(11,12)$. Alat lain yang lebih sensitif adalah CT scan yang memiliki sensitifitas 100\% dan spesifitas 95\% (13), tapi USG tetap menjadi pilihan karena biaya CT scan lebih mahal dan akan membebani pasien terutama pasien kelas 3.

Berdasarkan SPO RSWH appendiktomi merupakan operasi cito, tapi operasi cito tidak diterapkan pada semua pasien. Cito adalah tindakan medik dan terapi yang harus dilakukan segera dan tidak dapat ditunda untuk menyelamatkan jiwa pasien. Tindakan cito diperlukan karena menunda operasi bisa meningkatkan komplikasi infeksi dan memperlama masa perawatan. Penundaan hanya bisa dibenarkan apabila dokter belum bisa memastikan diagnosa (14).

Obat yang dipakai di RSWH sangat beragam baik jenis, nama maupun harganya. Harga obat bervariasi tergantung pada merk, bahkan untuk kandungan yang sama. Perbedaan harga obat akan sangat mempengaruhi biaya yang dikeluarkan pasien karena obat merupakakan salah satu komponen penentu biaya. Pemakaian obat mahal dan bermerk tidak menjamin masa perawatan menjadi pendek. Perbedaan harga antara obat bermerk dan generik karena beberapa faktor, diantaranya adalah: obat bermerk melakukan promosi (termasuk melalui detailer) sedangkan obat generik tidak. Harga obat bermerk ditentukan oleh mekanisme pasar dengan mempertimbangkan kompetitor sedangkan obat generik ditentukan oleh biaya produksi. Harga obat generik ditentukan oleh pemerintah sedangkan obat bermerk tidak. Walaupun harga berbeda, penelitian menunjukkan bahwa kualitas obat bermerk tidak lebih baik jika dibandingkan dengan generik $(15,16)$.

Appendiktomi merupakan tindakan yang cukup berisiko bagi pasien sehingga diagnosa harus bisa ditegakkan dengan benar sebelum dilakukan tindakan dan pasca tindakan dilakukan pemeriksaan ulang secara patologi anatomi (PA). Pemeriksaan PA sampai sekarang merupakan gold standard appendicitis acuta (17). Dengan dilakukan pemeriksaan PA akan memastikan diagnosa sehingga bisa memberikan perlindungan hukum apabila dikemudian hari ada tuntutan, sebagai alat kontrol dalam menentukan kualitas pelayanan rumah sakit dan sebagai bahan masukan ketika akan melakukan audit.

Hasil menunjukkan adanya variasi biaya antara ke 3 dokter baik rerata pada seluruh kelas maupun pasien kelas III. Analisa regresi linier menunjukkan bahwa variasi biaya pasien appendicitis acuta RSWH paling besar dipengaruhi oleh faktor biaya tindakan dan faktor kedua adalah biaya obat. Biaya tindakan paling besar dipengaruhi oleh biaya dokter operator karena biaya seluruh anggota tim disesuaikan dengan biaya dokter operator dengan prosentase tertentu. Biaya operator ini sangat dipengaruhi oleh dokter secara personal, bukan cito elektifnya maupun besar kecilnya jenis operasi. Apabila biaya tindakan dan obat bisa dikendalikan maka biaya perawatan secara keseluruhan juga bisa ditekan. Pengendalian biaya bisa meningkatkan angka kunjungan rumah sakit karena salah satu pertimbangan pasien dalam memilih rumah sakit adalah biaya. Jumlah biaya yang wajar dan terjangkau serta adanya kepastian akan mendorong pasien untuk memanfaatkan jasa sebuah rumah sakit seperti terlihat dari tingginya angka tindakan operasi persalinan di RSWH.

Analisa regresi linier sederhana untuk mengetahui hubungan antara biaya total perawatan dengan lama perawatan menunjukkan bahwa biaya total perawatan yang mahal tidak memperpendek masa perawatan, bahkan lebih panjang walaupun pengaruhnya hanya $29,8 \%$. Variabel yang mempengaruhi biaya total perawatan salah satunya adalah biaya obat sehingga bisa disimpulkan bahwa pemakaian obat yang mahal tidak 
mempercepat masa perawatan.

Sebelum masuk rumah sakit (MRS) pasien sudah harus mengetahui perkiraan jumlah biaya agar bisa memutuskan apakah akan menggunakan jasa rumah sakit tersebut dan kamar perawatan yang sesuai atau menggunakan rumah sakit lain. Jumlah biaya yang diperkirakan tidak boleh terlalu jauh berbeda dengan yang dibayarkan. Perkiraan dan pengendalian biaya bisa dilakukan dengan mengontrol faktor-faktor penyebabnya, salah satunya adalah dengan penerapan CP. Penerapan $\mathrm{CP}$ oleh dokter senior yang telah menangani banyak pasien lebih baik jika dibandingkan dengan yang masih yunior (18).

Variasi yang terjadi dalam pelayanan appendicitis acuta bisa dikurangi dengan menerapkan CP. CP adalah suatu konsep perencanaan pelayanan terpadu yang merangkum setiap langkah yang dilakukan kepada pasien mulai masuk sampai keluar RS berdasarkan standar pelayanan medis dan praktek kedokteran terbaik yang berbasis bukti, sesuai dengan harapan pasien, hasil yang dapat diukur dan dalam jangka tertentu selama di rumah sakit. Tujuannya adalah untuk meningkatkan kualitas pelayanan, mengurangi risiko, meningkatkan kepuasan dan meningkatkan efisiensi penggunaan sumber daya. Dalam pembuatannya clinical pathways harus melibatkan setiap profesi yang menangani pasien dan sesuai dengan kondisi rumah sakit (19).

Manajemen rumah sakit dan setiap profesi yang terlibat dalam menangani pasien appendicitis terlibat dalam menyusun clinical pathway RSWH sehingga format yang dihasilkan sesuai dengan kondisi rumah sakit, bisa dilaksanakan dan sesuai dengan kebijakan manajemen. Beberapa hal pokok format clinical pathway appendicitis acuta di RSWH adalah: masa perawatan, kelas perawatan, gejala dan pemeriksaan klinis, pemeriksaan penunjang, obat-obatan dan nutrisi.

Masa perawatan yang direncanakan adalah 4 hari sesuai dengan penanganan pasien appendicitis acuta tanpa komplikasi yaitu 3 sampai 4 hari. Studi pustaka menunjukkan bahwa masa rawat inap pasien appendictomy bervariasi, tergantung pada kondisi rumah sakit, pasien, jenis operasi dan sebagainya. Rumah sakit dr. Kariadi rata-rata lama perawatan adalah 3,8 hari, Inggris bisa 2 hari dan penelitian lain 2,61 hari dan akan lebih pendek bila dengan laparoskopi (20). CP disusun untuk pasien appendicitis acuta tanpa komplikasi kelas 3. Salah satu pertimbangan menerapkan CP untuk pasien kelas 3 adalah untuk mengendalikan biaya tanpa mengurangi kualitas pelayanan karena biaya menjadi faktor yang sangat penting bagi pasien kelas 3 .

\section{DAFTAR PUSTAKA}

1. Hardin DM Jr. Acute Appendicitis: Review and Update. American Family Physician. 1999; 60(7): 2027-2034.

2. Busch M, Gutzwiller FS, Aellig S, Kuettel R, Metzger U, and Zingg U. In-Hospital Delay Increases the Risk of Perforation in Adults with Appendicitis. World Journal of Surgery. 2011; 35(7): 1626-1633.

3. Panella M, Marchisio S, and Di Stanislao F. Reducing Clinical Variations with Clinical Pathways: Do Pathways Work? International Journal for Quality in Health Care. 2003; 15(6): 509-521.
Keterampilan dalam menemukan gejala dan melakukan pemeriksaan klinis sangat membantu dalam menegakkan diagnosa. Pemeriksaan ini perlu pengalaman karena gejala klinis yang ditimbulkan sering berbeda pada setiap orang dan jenis appendicitis, misalnya retrocaecal appendicitis dan tipe classical gejalanya berbeda (21). Hampir semua pasien mengalami nyeri perut sehingga apabila terdapat gejala ini perkiraan diagnosa appendicitis harus mulai dipikirkan. Tanda klinis lain yang sangat penting adalah nyeri tekan abdomen quadrant kanan bawah pada palpasi, jumlahnya $96 \%(22)$.

Beberapa pemeriksaan klinis bisa dilakukan untuk menegakkan diagnosa, diantaranya adalah: nyeri lepas tekan, Rovsing's Sign, Psoas Sign, Obturator Sign, Blumberg Sign, dan Rectal Toucher. Pemeriksaan ini cukup sederhana dan bisa dilakukan oleh setiap dokter, terutama yang telah mengikuti pelatihan. Pemeriksaan nyeri lepas tekan cukup bermakna dalam mendiganosa appendicitis, terutama bila pemeriksaan lain memberikan gambaran negatif. Walaupun tingkat spesifitasnya rendah tapi sensitivitasnya tinggi. Pemeriksaannnya cukup sederhana dan tidak sulit untuk diinterpretasikan, tapi perlu dilakukan secara hati-hati agar tidak memperparah penyakit dan meningkatkan nyeri pasien (23). Pasien appendicitis pada pemeriksaan Rovsing's sign dan Psoas sign memberikan gambaran positif masing-masing $92 \%$ dan $80 \%$. Obsturator sign dan Blumberg sign juga perlu diperiksa karena bisa membantu dalam menegakkan diagnosa appendicitis(24).

Antibiotika diberikan karena walaupun metode asepsis dan tehnik operasi selalu diperbaiki, komplikasi pasca operasi seperti infeksi dan intra abdominal masih sering terjadi. Komplikasi pasca operasi ini angka kejadiannnya bisa diturunkan dengan pemberian antibiotika yang sesuai (25). Antibiotika yang cukup efektif untuk mencegah timbulnya infeksi pada operasi abdominal adalah ceftriaxon dan cefotaxim, tapi ceftriaxon lebih efektif terhadap kuman Staphilococcus aureus dan waktu paruhnya lebih panjang sehingga lebih diutamakan jika dibandingkan dengan cefotaxim (16). Obat simtomatis hanya diberikan apabila pasien membutuhkan dan yang menjadi pilihan adalah ketorolac dan ranitidine.

Kajian ini membuktikan adanya variasi pelayanan yang seharusnya dapat dikendalikan dengan pengembangan CP. Variasi biaya sangat dipengaruhi oleh operator dan obat sehingga seharusnya dapat dikendalikan dengan penggunaan obat generik, standar biaya operator dan standar pemeriksaan sesuai dengan bukti ilmiah yang kuat. Penggunaan obat generik dapat disarankan dalam CP karena tidak memberikan perbedaan keluaran pelayanan (lama perawatan) dengan selisih biaya yang sangat tinggi.

4. Porter GA, Pisters PW, Mansyur C, et al. Cost and Utilization Impact of a Clinical Pathway for Patients Undergoing Pancreatico duodenectomy. Annals of Surgical Oncology. 2000; 7(7): 484-489.

5. Hanna E, Schultz S, Doctor D, Vural E, Stern S, and Suen J. Development and Implementation of a Clinical Pathway for Patients Undergoing Total Laryngectomy: Impact on Cost and Quality of Care. OtolaryngologyHead \& Neck Surgery. 1999; 125(11): 1247-1251.

6. Cheah J. Development and Implementation of a Clinical Pathway Programme in an Acute Care General Hospital in Singapore. International Journal for 
Quality in Health Care. 2000; 12(5): 403-412.

7. Krismanuel H. Pemulangan Awal dari Rumah Sakit Sesudah Appendisektomi Terbuka Hubungannya dengan Luka Operasi dan Penerimaan Penderita. [Tesis]. Universitas Diponegoro, Semarang. 2002.

8. Nasiri S, Mohebbi F, Sodagari N, and Hedayat A. Diagnostic Values of Ultrasound and the Modified Alvarado Scoring System in Acute Appendicitis. International Journal of Emergency Medicine. 2012; 5(1): 1-5.

9. Flum DR and Koepsell T. The Clinical and Economic Correlates of Misdiagnosed Appendicitis: Nationwide Analysis. Archives of Surgery. 2002; 137(7): 799-804.

10. Fung HS, Lau S, Siu JCW, Chan CM, and Chan SCH. Audit of Ultrasonography for Diagnosis of Acute Appendicitis: A Retrospective Study. Hong Kong Journal of Radiology. 2008; 11: 108-111.

11. Jahangir $T$ and Roy MK. Evaluation of Negative Appendicectomy Rate in Cases of Suspected Acute Appendicitis and to Study the Usefulness of Ultrasonography in Improving the Diagnostic Accuracy. Indian Journal of Surgery. 2007; 71(2): 109110.

12. Lessin MS, Chan M, Catallozzi M, et al. Selective Use of Ultrasonography for Acute Appendicitis in Children. The American Journal of Surgery. 1999; 177(3): 193196.

13. Ünlü Ç, de Castro SM, Tuynman JB, et al. Evaluating Routine Diagnostic Imaging in Acute Appendicitis. International Journal of Surgery. 2009; 7(5): 451-455.

14. Eldar S, Nash E, Sabo E, et al. Delay of Surgery in Acute Appendicitis. The American Journal of Surgery. 1997; 173(3): 194-198.

15. Yunarto N. Revitalisasi Obat Generik: Hasil Uji Disolusi Obat Generik Tidak Kalah dengan Obat Bermerk.
Media Penelitian dan Pengembangan Kesehatan. 2010; 20(4): 198-201.

16. Walling AD. Ceftriaxone vs Cefotaxime in Abdominal Surgery. American Family Physician. 2003; 67(11): 2405.

17. Darmono $\mathrm{P}$ dan Rochadi S. Validitas Pemeriksaan Ultrasonografi dalam Menegakkan Diagnosis Apendisitis Akut pada Anak. [Tesis]. Universitas Gadjah Mada, Yogyakarta. 2006.

18. Leibman B, Dillioglugil O, Abbas F, Tanli S, Kattan M, and Scardino P. Impact of a Clinical Pathway for Radical Retropubic Prostatectomy. The Journal of Urology. 1998; 52(1): 94-99.

19. De Bleser L, De Preitere R, De Waele K, Vanhaecht K, Vlayen J, and Sermeus W. Defining Pathways. Journal of Nursing Management. 2006; 14(7): 553-563.

20. Martin LC, Puente I, Sosa JL, et al. Open Versus Laparoscopic Appendectomy. A Prospective Randomized Comparison. Annals of Surgery. 1995; 222(3): 256-262.

21. Wani I. K-Sign in Retrocaecal Appendicitis: A Case Series. Cases Journal. 2009; 2(1): 157.

22. Old JL, Dusing RW, Yap W, and Dirks J. Imaging for Suspected Appendicitis. American Family Physician. 2005; 71(1): 71-78.

23. Alshehri M, Ibrahim A, Abuaisha $N$, et al. Value of Rebound Tenderness in Acute Appendicitis. East African Medical Journal. 1995; 72(8): 504-506.

24. Marrero Jr RR, Barnwell S, and Hoover EL. Appendicitis in Children: a Continuing Clinical Challenge. Journal of the National Medical Association. 1992; 84(10): 850.

25. Andersen BR, Kallehave F, and Andersen H. Antibiotics Versus Placebo for Prevention of Postoperative Infection after Appendicectomy. Cochrane Database of Systematic Reviews. 2003; (2): CD001439. 